\title{
Formation and availability of methylmercury in mercury-contaminated sediment: effects of activated carbon and biochar amendments
}

\author{
Erlend Sørmo ${ }^{1,2} \circledast$ - Ludovica Silvani ${ }^{1} \cdot$ Hans Fredrik Veiteberg Braaten ${ }^{3} \cdot$ Tina Bryntesen $^{3} \cdot$ Espen Eek $^{1}$. \\ Gerard Cornelissen ${ }^{1,2}$
}

Received: 20 August 2021 / Accepted: 29 December 2021 / Published online: 14 January 2022

(c) The Author(s) 2022

\begin{abstract}
Purpose As the formation of toxic and bioaccumulative methylmercury $(\mathrm{MeHg})$ in $\mathrm{Hg}$-contaminated sediments is of great concern worldwide, suitable remediation options are needed. Activated carbon (AC) amendment is a contested alternative due to uncertainties surrounding sorption efficiency and its potential role in aiding $\mathrm{MeHg}$ formation. The purpose of this study was therefore to demonstrate $\mathrm{AC}$ performance under favourable conditions for $\mathrm{Hg}$-methylation and to further understand the role AC plays in the methylation process.

Materials and methods Mercury-contaminated sediment $\left(57.1 \mathrm{mg} \mathrm{kg}^{-1}\right)$ was sampled from the Gunneklev fjord, a site known as the most heavily contaminated fjord in Norway. In a laboratory experiment, lignite AC (A-AC, 5\%) or activated biochar (A-BC, 5\%) along with dried algae biomass, serving as an excess source of easily degradable organic matter (OM) and sulphate, were added to sediment samples that were kept anoxic and dark over a period of 12 months.

Results and discussion The amount of $\mathrm{MeHg}$ in sediment and porewater of the amended samples were measured at $0,1,3$, 6, and 12 months and compared to an unamended control. A net increase of $\mathrm{MeHg}$ in the sediment was observed in both control and amended samples, but contrary to expectations, sediment MeHg was 5 and 3 times higher in the A-AC and A-BC treatments, respectively, relative to the control after 12 months. As the stimulation of $\mathrm{Hg}$-methylation could not be attributed to the sorbents supplying more available OM or sulphate for dissimilatory sulphate reduction, it is speculated that the sorbents rather aid this process through shuttling of electrons between the substrates involved. Meanwhile, the A-AC and A-BC amendments strongly reduced the available $\mathrm{MeHg}$-concentration in porewater (by $87 \%$ for A-AC and by $93 \%$ for A-BC after 12 months), confirming that AC sorbents can be used to effectively limit the transport of MeHg from sediments. Conclusion When considering remediation of OM-rich $\mathrm{Hg}$-contaminated sediments with AC, caution is thus warranted, as the overall effect of reducing MeHg-transport out of the sediment could partly be offset by an increased fraction of $\mathrm{MeHg}$ in the sediment. Thin-layer capping with AC might therefore be preferable to complete mixing of AC and sediment.
\end{abstract}

Keywords Methylmercury $\cdot$ Methylation $\cdot$ Sediment remediation $\cdot$ Activated carbon $\cdot$ Activated biochar

\section{Introduction}

Responsible editor: Nives Ogrinc

Erlend Sørmo

ers@ngi.no

1 Norwegian Geotechnical Institute (NGI), Oslo, Norway

2 Faculty of Environmental Science and Natural Resource Management (MINA), University of Life Sciences (NMBU), Ås, Norway

3 Norwegian Institute for Water Research (NIVA), Oslo, Norway
Mercury $(\mathrm{Hg})$ pollution is a widespread contamination issue throughout the world, in industrial as well as remote areas (Fernandez-Luqueno et al. 2013). Methylation of inorganic $\mathrm{Hg}$ to methylmercury $(\mathrm{MeHg})$ takes place under anoxic conditions and increases the overall risk of $\mathrm{Hg}$ due to the higher toxicity and bioaccumulation potential of $\mathrm{MeHg}$ as compared to inorganic $\mathrm{Hg}$ (Magos et al. 1985; Ullrich et al. 2001; Clarkson et al. 2003). Biotic methylation processes dominate overall $\mathrm{MeHg}$ production in most systems (Ullrich et al. 2001), and sulphur reducing 
bacteria (SRB) have been identified as the main methylators in marine sediments (Regnell and Watras 2019).

Below the top millimetres to centimetres, contaminated coastal marine sediments are often anoxic (Dell'Anno et al. 2009), and conducive to the formation of $\mathrm{MeHg}$, especially in the presence of fresh, easily degraded organic matter (OM) that can serve as electron donor (Ndungu et al. 2016). $\mathrm{Hg}$ contamination is often so widespread that traditional dredging and containment technologies are not feasible. However, the placement of sand or clay caps as remediation measures can lead to an upward extension of anoxic conditions in initially oxic sediments and subsequently result in increased MeHg formation (Johnson et al. 2010). On the other hand, Ndungu et al. (2016) demonstrated that although a thin clay capping layer increased $\mathrm{MeHg}$ formation, $\mathrm{OM}$ added as algae was the limiting factor in this process and the cap succeeded in reducing the release of said $\mathrm{MeHg}$. Due to the contentious effect of other remediation approaches, addition of actively sorbing materials such as biochar or activated carbon (AC) has been suggested as a methodology to reduce total $\mathrm{Hg}(\mathrm{THg})$ and $\mathrm{MeHg}$ porewater concentrations, and thus risk (Gomez-Eyles et al. 2013).

Biochar is a highly carbonaceous material made through the heating of biomass in the absence of oxygen (pyrolysis), while $\mathrm{AC}$ is a term used to describe carbonaceous materials (often hard coals such as lignite or anthracite) that have been subjected to an activation process to increase porosity and optimize surface chemistry (Hagemann et al. 2018). Traditional AC manufactured from fossil hard coal has been shown to exhibit effective sorbent properties (Cornelissen et al. 2012; Patmont et al. 2015), but biochar has the advantage of being a more sustainable option for sediment remediation in a life cycle perspective (Sparrevik et al. 2011; Alhashimi and Aktas 2017). It should be noted however that the sorbent properties of biochars vary greatly with feedstock, pyrolysis temperature and retention time (Lehmann and Joseph 2015). AC has been proven to function well for hydrophobic organic chemicals (Ghosh et al. 2011; Patmont et al. 2015). A few studies have shown that AC, and to a slightly lesser extent biochar, also bind $\mathrm{Hg}$, and especially $\mathrm{MeHg}$, very strongly (Kong et al. 2011; Gomez-Eyles et al. 2013). This is especially true for sediments that show intrinsically weak sorption of $\mathrm{Hg}$ and $\mathrm{MeHg}$ (Gilmour et al. 2013).

There is no scientific consensus on the effect of biochar and $\mathrm{AC}$ on total $\mathrm{MeHg}$ in sediments. For example, Bussan et al. (2016) measured reduced $\mathrm{Hg}$-methylation rates in environmentally contaminated sediments with both AC and biochar. However, no measurements of porewater or bioavailability were done. One study found total sediment concentration of $\mathrm{MeHg}$ to stay constant upon AC amendment (Gilmour et al. 2013), whereas another field study on $\mathrm{AC}$ and biochar amendment to sediment by the same group observed enhanced $\mathrm{MeHg}$ formation, especially in the presence of biochar that added more degradable $\mathrm{OM}$ than AC (Gilmour et al. 2018). Around 20\% of biochar carbon is not stable over prolonged time periods of more than a decade (Lehmann et al. 2009), and the labile carbon released may serve as an electron donor for bacteria in the $\mathrm{Hg}$ methylation process Also Liu et al. (2018), in a 500-day microcosm study where various biochars were added to Hg-contaminated sediment, observed 3- to tenfold increase in total $\mathrm{MeHg}$ contents in the sediment, especially for high-temperature chars $\left(600-700{ }^{\circ} \mathrm{C}\right)$. Two studies on inundated rice paddies found increases in overall $\mathrm{MeHg}$ concentrations in the paddy soils upon the addition of biochars, by 20-80\% (Shu et al. 2016) and 5-75\% (Zhang et al. 2018). It is unknown why $\mathrm{AC}$ and biochar have been observed to stimulate $\mathrm{MeHg}$ production, but the main hypothesis seems to be that the addition of $\mathrm{AC}$ or biochar might provide additional OM or sulphate that in many systems are limiting factors for $\mathrm{Hg}$-methylation.

The net $\mathrm{MeHg}$ porewater concentration following amendment is expected to be the result of the extent of $\mathrm{MeHg}$ produced through methylation and the amount of $\mathrm{MeHg}$ removed through the partitioning to the sorbents. Previously, the extensive sorption effect was observed to be stronger than the MeHg formation effect, leading to overall lower $\mathrm{MeHg}$ bioavailability despite the formation of $\mathrm{MeHg}$ (Shu et al. 2016; Gilmour et al. 2018; Liu et al. 2018; Zhang et al. 2018). As mentioned above, however, methylation was likely limited in these studies by the access of methylating bacteria to suitable electron donors and acceptors.

More work is thus needed to better understand the possible limitations of $\mathrm{AC}$ or biochar amendment of $\mathrm{Hg}$-contaminated sediment. To this end, a highly Hg-contaminated marine sediment was amended with AC made from fossil hard coal (A-AC), as well as an activated biochar made from coconut shell (A-BC), and analysed for MeHg concentrations in both the sediment and the porewater at various time intervals.

In contrast to previous studies on sorbent amendments of $\mathrm{Hg}$ contaminated sediments where $\mathrm{MeHg}$ production was limited by the presence of OM or sulphate, sorbent effectiveness is here tested in a scenario where there are no limiting factors for methylation. Such a scenario is considered relevant in a purely mechanistical perspective but also relevant as a scenario where an OM-rich sediment with favourable conditions for methylation is amended. Furthermore, this study offers a comparison between the efficiency of the more sustainable activated biochar sorbent compared to a traditional activated carbon made from fossil hard coal. Porewater concentrations were used as a measure of amendment efficiency as this fraction is both relevant for uptake in organisms (Amirbahman et al. 2013; Gilmour et al. 2013) and transport from the sediment to the water column (Ndungu et al. 2016). 
The following hypotheses were tested: (H1) A-AC and A-BC sorbent amendment will not enhance $\mathrm{MeHg}$ production in a system where excess amounts of $\mathrm{OM}$ and sulphate are present and (H2) Both A-AC and A-BC amendments will prove effective for sediment $\mathrm{Hg}$-remediation by strongly reducing porewater $\mathrm{MeHg}$ concentrations.

\section{Materials and methods}

\subsection{Study site}

The Gunneklev fjord is a $0.76-\mathrm{km}^{2}$ fjord in the inner part of the larger Inner Grenlandsfjord (Frierfjord) in the province of Telemark, Norway (Fig. 1). The Gunneklev fjord is closed off between the Herøya peninsula and the mainland, with a small inlet at the outlet of the Skien River. There is also a small outlet in the other end of the fjord through a small channel, built as an exit from the Gunneklev fjord into the Inner Grenlandsfjord for small recreational boats from the marina situated in the inner part of the Gunneklev fjord. The Gunneklev fjord is a brackish fjord (salinity 5-20 PSU in the bottom water (Olsen et al. (2018) and references therein) with an average depth of $4.6 \mathrm{~m}$ and water volume of $3.5 \times 10^{6} \mathrm{~m}^{3}$. It is one of the most polluted fjord systems in Norway due to historic release of $\mathrm{Hg}$-containing sludge from a chlor-alkali plant (Olsen et al. 2018). Previous studies have shown sediment concentration ranges of total mercury (THg) ranging from 2 to $5 \mathrm{mg} \mathrm{kg}^{-1}$ at the $0-5 \mathrm{~cm}$ surface layer to $500 \mathrm{mg} \mathrm{kg}^{-1}$ at $10-20 \mathrm{~cm}$ depth, and $\mathrm{MeHg}$ of $1-3 \mu \mathrm{g} \mathrm{kg}^{-1}$ at the surface to $300 \mu \mathrm{g} \mathrm{kg}^{-1}$ at $10-20 \mathrm{~cm}$ depth (Olsen et al. 2018). It has been estimated that the fjord contains about 20 to 30 tonnes of $\mathrm{Hg}$, of a total of 80 tonnes released from Herøya Industrial Complex between 1947 and 1987 (Olsen et al. 2019). Despite the high sediment concentrations, $\mathrm{Hg}$ concentrations in the water column are

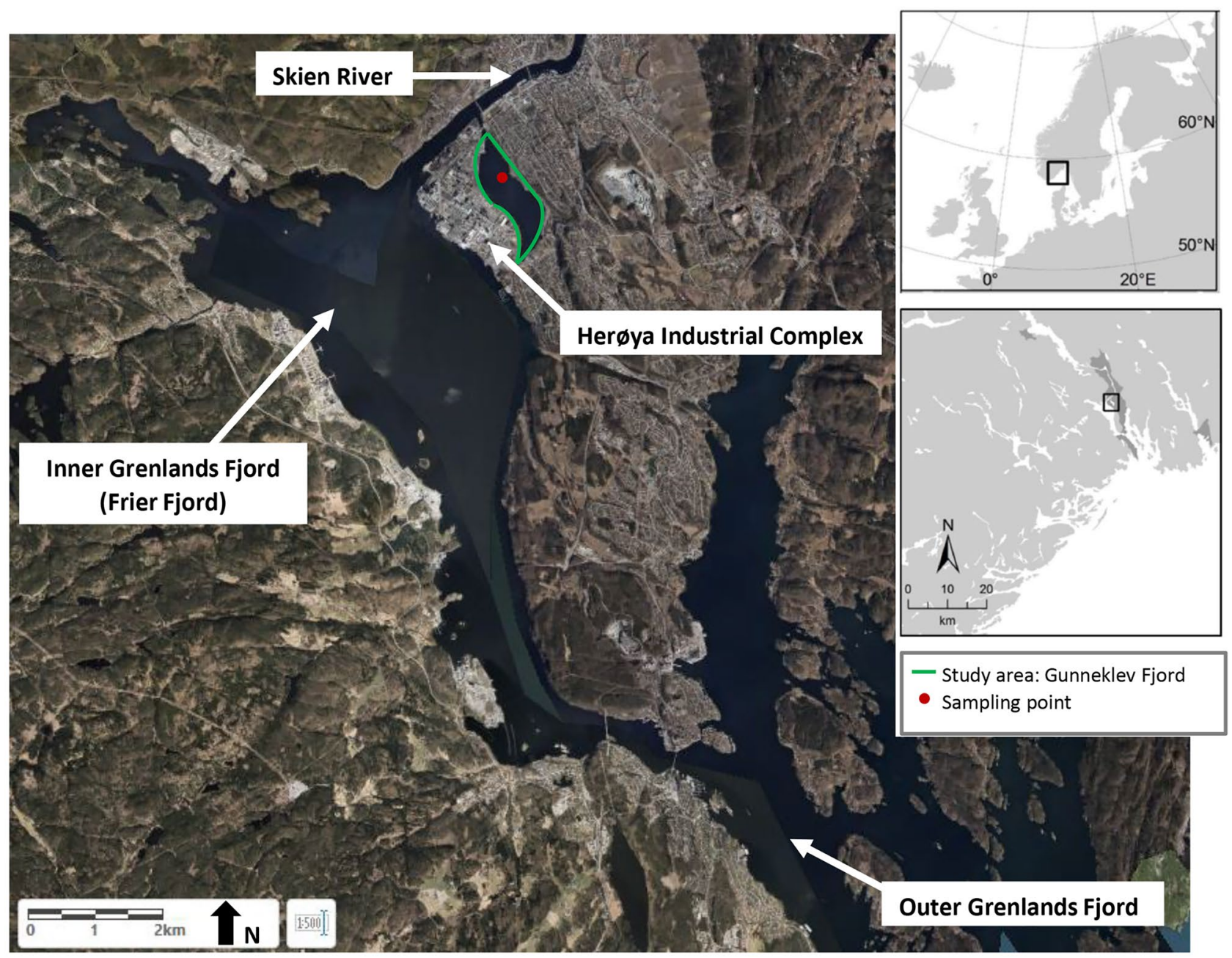

Fig. 1 Map showing the sampling point in the heavily contaminated Gunneklev Fjord, with the adjacent Herøya Industrial Complex at the innermost part of the Grenland Fjord in Telemark Province, Norway 
not significantly higher than in nearby freshwater lakes fed by atmospheric $\mathrm{Hg}$-transport, but the $\mathrm{Hg}$ concentrations in fish are elevated, indicating that the legacy pollution is still accumulating in the food webs (Braaten et al. 2019).

\subsection{Sediment sampling}

Surface sediment was sampled using a Van Veen grab sampler at approximately $0-10 \mathrm{~cm}$ depth. The sample was collected at latitude 59.12528859 and longitude 9.636577517 (WGS 84, UTM32), in a PE bucket (20 L) with a sealed lid, which was stored cold $\left(4{ }^{\circ} \mathrm{C}\right)$ and dark until use.

\subsection{Experimental setup}

The bulk sediment sample was homogenized through slow stirring $(\approx 10 \mathrm{~min})$ and split into three subsamples $(\approx 5 \mathrm{~L}$ each): (1) Control, (2) A-AC amendment, and (3) A-BC amendment. Each of the three subsamples was added chlorella algae ( $2 \%$ per d.w. sediment). Similar to the study by Ndungu et al. (2016), Chlorella algae was obtained from a Naturalis AS, Norway - a pure (100\% algae) and dried powder, sold as a dietary supplement.

The A-AC and A-BC were then added (5\% of d.w.) to subsamples (2) and (3), respectively (see section below for more details about the sorbents). All three subsamples were then homogenized thoroughly by stirring $(\approx 10 \mathrm{~min})$ before they each were split into five identical, pre-cleaned glass jars $(500 \mathrm{~mL})$ that were to represent a time series of 0 , $1,3,6$, and 12 months. The glass jars were filled nearly to the rim and topped off with saltwater from $60 \mathrm{~m}$ depth collected at the Norwegian Institute for Water Research (NIVA) research station at Solbergstrand, Norway, before they were sealed with lids and stored dark at $20^{\circ} \mathrm{C}$ until the completion of the respective time series. Gas produced in the sealed jars was released at regular intervals by carefully loosening the lid.

This experimental setup was chosen to mimic stratified marine waters with little or no exchange in the water column above the anoxic sediment surface. When contaminated with $\mathrm{Hg}$, such locations are considered among potential hot spots for methylmercury production (Ullrich et al. 2001; Hammerschmidt and Fitzgerald 2004; Merritt and Amirbahman 2009; Dai et al. 2021). Not exchanging the water above the surface sediment might lead to a higher accumulation of $\mathrm{MeHg}$ in porewater and sediment, as according to Fick's first law (Fick 1855), diffusive flux is controlled by the concentration gradient. This potential artefact is not considered an issue as it would further promote the high MeHg environment; the experimental setup was created to promote.

\subsection{Sorbent materials}

One fossil hard coal-based AC material fabricated from lignite (A-AC; BP2 fine powder) and one activated biomassbased material fabricated from coconut shells (A-BC; activated biochar; $\mathrm{CP} 1$ fine powder) were obtained from Jacobi Carbons, Kalmar, Sweden. Both AC qualities were of the same particle size range (average particle size $20 \mu \mathrm{m}, 80 \%$ smaller than $45 \mu \mathrm{m}$ ) and were produced using high temperature steam activation. Steam activation generally requires temperatures $>850^{\circ} \mathrm{C}$ (Marsh and Reinoso 2006). The characteristics of these materials have extensively been described in Amstaetter et al. (2012). A-AC exhibited a large portion of pores $>15 \AA\left(541 \mathrm{~m}^{2} \mathrm{~g}^{-1}\right)$. In contrast, a clear dominance of narrow pores in the size range of 3.5-15 $\AA$ was observed for the A-BC, and almost 10 times lower pore surface area $>15 \AA\left(61 \mathrm{~m}^{2} \mathrm{~g}^{-1}\right)$ than A-AC. The volume of larger pores $>15 \AA$ in A-BC $\left(0.053 \mathrm{~cm}^{3} \mathrm{~g}^{-1}\right)$ was much lower than that in A-AC $\left(0.602 \mathrm{~cm}^{3} \mathrm{~g}^{-1}\right)$. In contrast, both the 3.5-15 pore surface area and volume were larger for the biomassbased A-BC ( $977 \mathrm{~m}^{2} \mathrm{~g}^{-1}$ and $0.322 \mathrm{~cm}^{3} \mathrm{~g}^{-1}$, respectively) than for the coal-based A-AC $\left(726 \mathrm{~m}^{2} \mathrm{~g}^{-1}\right.$ and $0.268 \mathrm{~cm}^{3} \mathrm{~g}^{-1}$, respectively) (Amstaetter et al. 2012).

\subsection{Sediment and porewater characterization}

Porewater was extracted from sediment samples through centrifugation (5000 rpm) of approximately $400 \mathrm{~g}$ sediment in pre-cleaned Teflon vials. The separated pore water phase was pipetted off into pre-cleaned glass vials $(50 \mathrm{~mL})$. The samples could not be analysed immediately and were therefore frozen after centrifugation to inhibit further methylation/demethylation of $\mathrm{Hg}$ and stored dark until analysed. Freezing samples is an accepted way of inhibiting changes in speciation post sampling induced by bacterial activity (Carr et al. 2001), and is commonly used for sediment samples for $\mathrm{Hg}$ analysis (Lutz et al. 2008). Freezing unfiltered porewater could alter distribution between dissolved and particle bound species, but post centrifugation particle content will be low and negligible effects are assumed (Carr et al. 2001). Freezing centrifuged porewater samples could potentially alter the DOC content however (Peacock et al. 2015), but as DOC was expected to be present in excess, this potential artefact was considered an acceptable trade off.

Aqueous (porewater) total $\mathrm{Hg}$ ( $\mathrm{THg}$ ) and $\mathrm{MeHg}$ was analysed following USEPA method 1631 and method 1630 as described in Braaten et al. (2014), including filtration at $0.45 \mu \mathrm{m}$, oxidation (for $\mathrm{THg}$ ) and distillation and ethylation (for $\mathrm{MeHg}$ ) followed by purge/trap and cold vapour atomic fluorescence (CVAFS) detection. Method detection levels (MDLs) were $0.02 \mathrm{ng} \mathrm{L}^{-1}$ and $0.1 \mathrm{ng} \mathrm{L}^{-1}$ for $\mathrm{MeHg}$ and $\mathrm{THg}$, respectively (3 standard deviations of method blanks). For 
both aqueous $\mathrm{Hg}$ species, automated systems were used for analysis (Brooks Rand Instruments MERX). Relative standard deviation (RSD) of sample duplicates was $<10 \%$ and $<20 \%$ for $\mathrm{THg}$ and $\mathrm{MeHg}$, respectively. Recoveries of matrix spikes were $80-120 \%$ for $\mathrm{MeHg}$ and $90-110 \%$ for $\mathrm{THg}$.

Sediment $\mathrm{THg}$ determination was done according to USEPA method 7473 using thermal decomposition and direct atomic absorption spectrophotometry (AAS) on a DMA-80 instrument from Milestone. Analysis of a THg certified reference material (CRM, Mess-4, marine sediment) was within the reported range $\left(0.09 \pm 0.04 \mathrm{mg} \mathrm{kg}^{-1}\right)$. MDL for $\mathrm{THg}$ was $0.7 \mu \mathrm{g} \mathrm{kg}^{-1}$ (3 standard deviations of method blanks) and RSD of sample duplicates was $<20 \%$.

The $\mathrm{MeHg}$ in sediments was extracted by methods described in detail by Bloom et al. (1997). The method includes leaching of $\mathrm{MeHg}$ from the sediment with potassium bromide $(\mathrm{KBr}, 18 \%)$, sulphuric acid $\left(\mathrm{H}_{2} \mathrm{SO}_{4}, 5 \%\right)$, and copper sulphate $\left(\mathrm{CuSO}_{4}, 1 \mathrm{M}\right)$ before extraction of the $\mathrm{MeHg}$ in the leachates into dichloromethane (DCM). The Hg was then back-extracted into DI water (by use of Whatman 1 PS silicone treated filter paper) before heating $\left(\approx 70{ }^{\circ} \mathrm{C}\right.$ for $\left.5 \mathrm{~h}\right)$. Determination followed USEPA Method 1630 as described above. Analysis of a MeHg CRM (ERMCC580; estuarine sediment) was within the reported range $\left(75 \pm 4 \mathrm{ng} \mathrm{g}^{-1}\right)$. MDL was $20 \mathrm{pg} \mathrm{g}^{-1}$ (3 std.dev. of blank extractions) based on a 0.05 -g sample weight.

For dissolved organic carbon (DOC) determination, porewater samples were filtered through $45 \mu \mathrm{m}$ syringe filters, before being analysed using catalytic combustion and infrared detection on an Apollo 9000 from Teledyne Tekmar as described in NS-EN 1484. Limit of quantification (LOQ) was $0.5 \mathrm{mg} \mathrm{L}^{-1}$ and method uncertainty $<20 \%$.

The $\mathrm{SO}_{4}{ }^{2-}$ in porewater was determined by photometry at $420 \mathrm{~nm}$ after precipitation of $\mathrm{BaSO}_{4}$ according to ISO15923 by the accredited laboratory ALS Laboratory Group Norge AS (ALS). LOD was $0.5 \mathrm{mg} \mathrm{L}^{-1}$ and method uncertainty $<10 \%$. $\mathrm{pH}$ of porewater was determined by potentiometry according to NS-EN-ISO10523 by ALS.

Sediment total water content was done by titration with Karl Fischer reagent (ISO760) with LOQ of $0.01 \%$ and method uncertainty of $\pm 9 \%$ by ALS. Sediment particle size distribution ( $>63 \mu \mathrm{m}$ and $<2 \mu \mathrm{m}$ ) according to internal standard CZ_SOP_D06_07_N11 with LOQ of 0.1\% and measurement uncertainty of $\pm 0.3 \% \mu \mathrm{m}$ for particles $>63 \mathrm{~m}$ and $\pm 0.5 \%$ for particles $<2 \mu \mathrm{m}$ by ALS. Total organic carbon (TOC) was determined coulometrically according to standard DIN-ISO10694 with LOQ of $0.01 \%$ by ALS.

\subsection{Data analysis}

In this experiment, remediation efficiency $\left(\mathrm{MeHg}_{\text {reduction }}\right.$, $\left.\mathrm{THg}_{\text {reduction }}, \%\right)$ was defined as the ability of the sorbent to reduce the $\mathrm{MeHg}$ and $\mathrm{THg}$ porewater concentration $\left(C_{\mathrm{pw}, \text { amended, }}\right)$ relative to the control $\left(C_{\mathrm{pw}, \mathrm{control}}\right)$ :

$\mathrm{Hg}_{\text {reduction }}=\left(1-\left(\frac{C_{\mathrm{pw}, \text { amended }}}{C_{\mathrm{w}, \text { control }}}\right)\right) \times 100$

As another measure of degree of sorption of $\mathrm{MeHg}$ to the sorbents, partitioning coefficients between water and sediment $\left(K_{D}\right)$ were calculated for the control and the sediment and AC sorbent mixtures using the following equation:

$K_{D}=C_{\text {sediment }} / C_{\mathrm{pw}}$

where $C_{\text {sediment }}$ is the concentration in the sediment or sediment + sorbent mixtures and $C_{\mathrm{pw}}$ is the concentration in extracted pore water. Under the experimental conditions, an anoxic sediment with available substrates for methylating bacteria, it should however be expected that $\mathrm{MeHg}$ does not reach a full equilibrium partitioning between sediment and water at any point due to continuous methylation and demethylation processes (Ullrich et al. 2001). In comparison to the fast adsorption processes of $\mathrm{Hg}$ species to AC, where $>80 \%$ of the adsorption happens within 3-6 $\mathrm{h}$ according to two studies by Ting et al. (2018) and $\mathrm{Li}$ et al. (2013), methylation rates are relatively slow $0.01 \mathrm{day}^{-1}$ (Hintelmann et al. 2000). It is therefore realistic to expect that the systems will be close to equilibrium. The partitioning coefficients, that assume equilibrium, will therefore be pseudo- $K_{D}$ that can be used as a conservative and comparative estimate of the sorption strength of the different sorbent amendments.

Single linear regression analyses and $t$-tests were done using the software R (v.3.4.3), and results were considered significant for $p<0.05$.

\subsection{Quality control and assurance}

Due to economic constraints, sample time points (sediment jars) were not replicated. The method uncertainty, which is related to the degree of homogenization of bulk samples before splitting and whether splitting and subsequent treatment of individual sample jars led to variation in contents or conditions, was tested by analysing sediment $\mathrm{THg}$ in all sample jars. THg in the sediment is not expected to change. As Fig. $2 \mathrm{H}$ shows, there were no apparent trends in sediment $\mathrm{THg}$ and no statistically significant differences between the control and the two amendments ( $t$-test, $p<0.05)$. The average sediment THg concentration across all treatments and time points $(n=15)$ was $52.5 \pm 5.3 \mathrm{mg} \mathrm{kg}^{-1}$, amounting to a $10.1 \%$ relative standard deviation of the method. The analytical uncertainty however (Sect. 2.4) was equal to or higher than $10 \%$ for all parameters in the time series studied $(\mathrm{THg}-10 \%, \mathrm{MeHg}$ 


\section{Porewater}
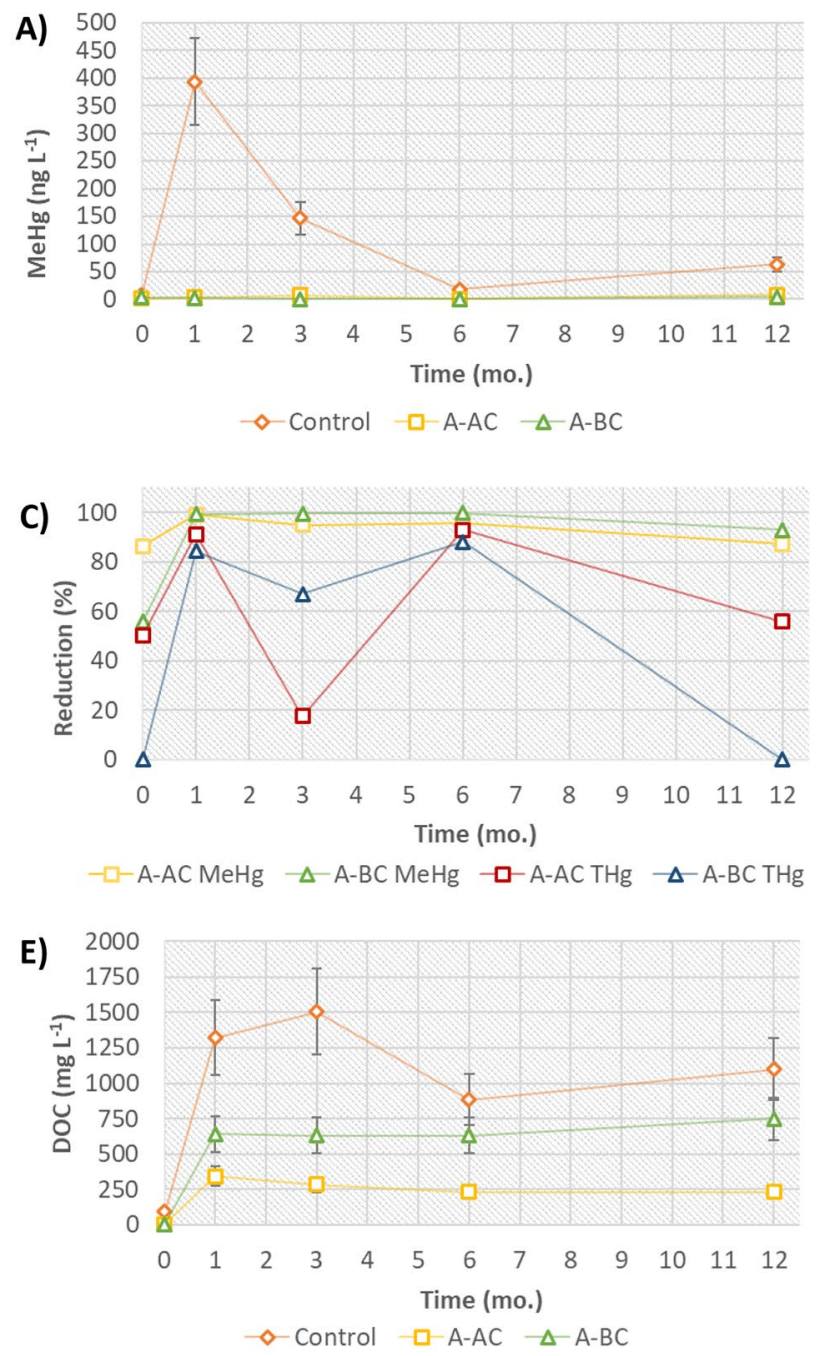

Sediment

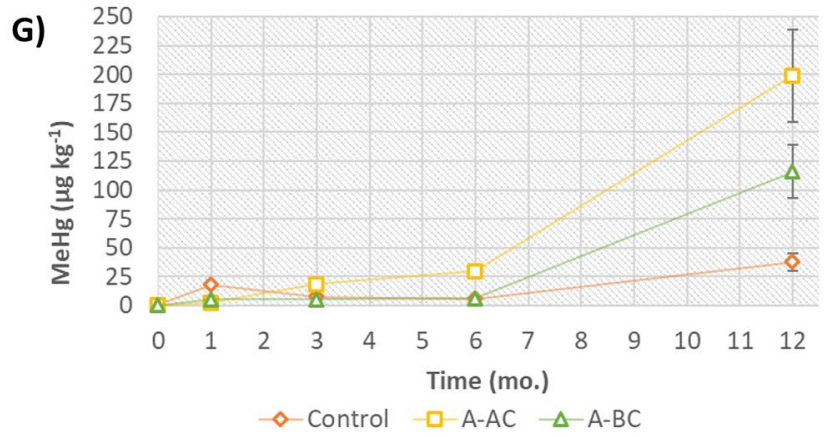

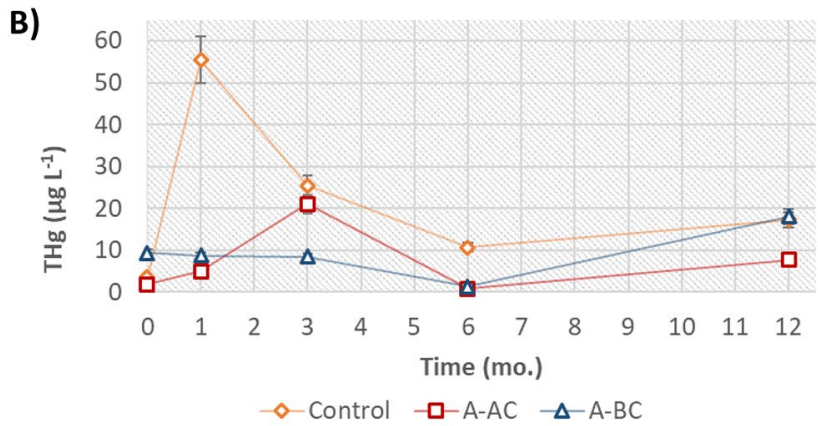

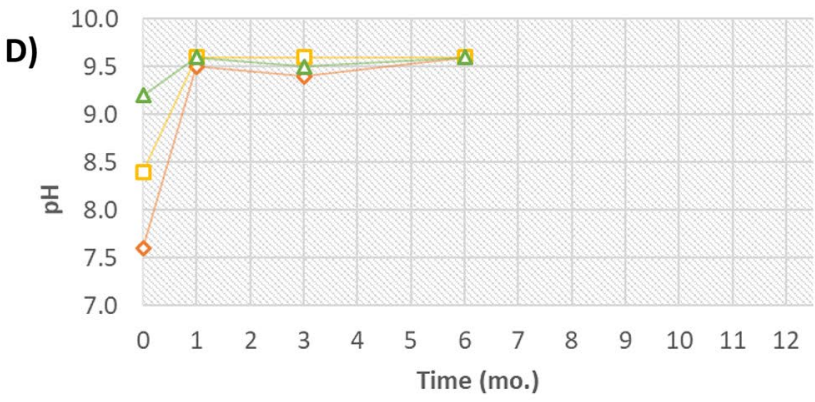

$\diamond$ Control $-\square-A-A C-\triangle-A-B C$
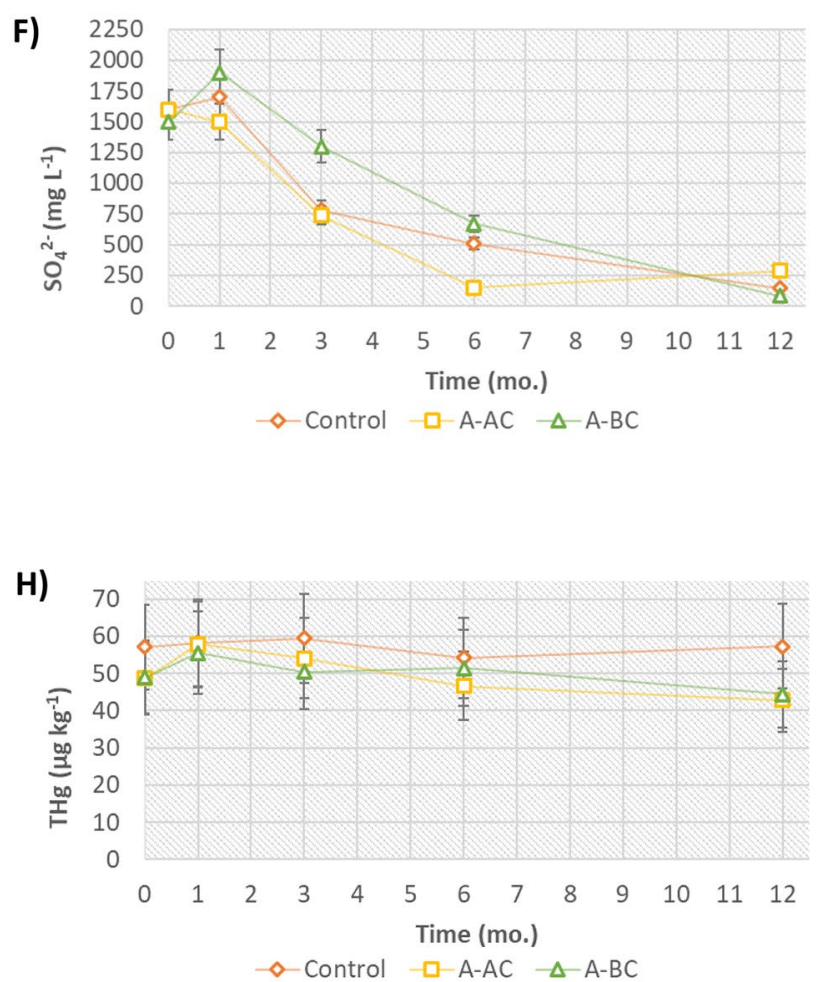

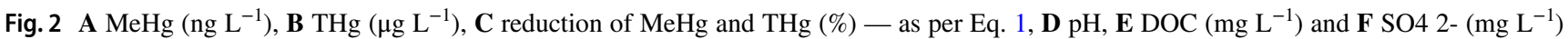
in porewater, and $\mathbf{G} \mathrm{MeHg}\left(\mu \mathrm{g} \mathrm{kg}^{-1}\right)$ and $\left.\mathrm{H}\right) \mathrm{THg}\left(\mathrm{mg} \mathrm{kg}^{-1}\right)$ in sediment. Error bars show the analytical uncertainty

$-20 \%, \mathrm{DOC}-20 \%$, and $\left.\mathrm{SO}_{4}{ }^{2-}-10 \%\right)$. In the absence of replications and since the analytical error was higher than the method error estimation, the analytical error was used as a measure of uncertainty for the individual sampling points. 


\section{Results}

\subsection{Sediment characterization}

The sediment from the Gunneklev fjord had a high water content $(84 \pm 9 \%)$ and a large amount of fine particles, with $90.6 \%$ of the particle diameter distribution being between 63 and $2 \mu \mathrm{m}$, and $3.0 \%$ below $2 \mu \mathrm{m}$. Furthermore, the sediment had an original TOC content of $5.56 \%$ d.w. and a porewater $\mathrm{pH}$ of 8.1 , with $\mathrm{SO}_{4}{ }^{2-}$ and $\mathrm{S}^{2-}$ concentrations of $900 \mathrm{mg} \mathrm{L}^{-1}$ and $0.12 \mathrm{mg} \mathrm{L}^{-1}$, respectively. Adding algae biomass ( $2 \%$ d.w.) to the samples supplied the sediment with about $1 \%$ of d.w. organic carbon, resulting in an immediate porewater DOC concentration of $90 \mathrm{mg}$ $\mathrm{L}^{-1}$, while increasing the porewater $\mathrm{SO}_{4}{ }^{2-}$ concentration to $1600 \mathrm{mg} \mathrm{L}^{-1}$ and lowering the $\mathrm{pH}$ to 7.6. At the onset of the experiment time series $\left(t_{0}, 0\right.$ months), THg sediment content was $57.1 \mathrm{mg} \mathrm{kg}^{-1}$, of which $0.9 \mu \mathrm{g} \mathrm{kg}^{-1}(0.0015 \%)$ was $\mathrm{MeHg}$. The $\mathrm{MeHg}$ concentration is in the lower range of what has previously been reported for the Gunneklev fjord (Olsen et al. 2018), and could have been affected by of aerobic demethylation during sample preparation (Ullrich et al. 2001).

\subsection{Methylmercury production in porewater and sediment}

Figure 2 shows development of porewater $\mathrm{MeHg}, \mathrm{THg}$, DOC and $\mathrm{SO}_{4}{ }^{2-}$, and sediment $\mathrm{MeHg}$ and $\mathrm{THg}$ over the duration of the experiment (0-12 months), while a full list of concentrations is presented in the supporting information (SI, Table S1).

The initial concentrations of $\mathrm{MeHg}$ in pore water and sediment were $9 \pm 2 \mathrm{ng} \mathrm{L}^{-1}$ and $0.9 \pm 0.2 \mu \mathrm{g} \mathrm{kg}^{-1}$, respectively as measured in the unamended control sample (i.e. in the presence of algae but without sorbent) at time zero (Fig. 2A). Conditions proved favourable for $\mathrm{Hg}$-methylation under the regime of the experimental setup, as a sharp increase in $\mathrm{MeHg}$ porewater concentration was observed in the control during the first month of the trial, increasing from the initial $9 \pm 2$ to $393 \pm 79 \mathrm{ng} \mathrm{L}^{-1}$. In the following months, the porewater concentration varied, by first dropping to $147 \pm 29$ and $18 \pm 4 \mathrm{ng}$ $\mathrm{L}^{-1}$ after 3 and 6 months, respectively, before increasing to $63 \pm 13 \mathrm{ng} \mathrm{L}^{-1}$ after 12 months (Fig. 2). The MeHg sediment concentration showed a similar trend: first a sharp increase, from $0.9 \pm 0.2$ to $18 \pm 4 \mu \mathrm{g} \mathrm{kg}^{-1}$, after 1 month, then a drop to $8 \pm 2$ and $6 \pm 1 \mu \mathrm{g} \mathrm{kg}^{-1}$ after 3 and 6 months, respectively, before a final increase to $38 \pm 8 \mu \mathrm{g} \mathrm{kg}^{-1}$ after 12 months (Fig. 2G).

The porewater concentrations of $\mathrm{MeHg}$ in the A-AC treated sediment were 8-100 times lower than those of the control but showed a similar trend over time: $1.2 \pm 0.2$, $3.7 \pm 0.7,7 \pm 1,0.8 \pm 0.2$, and $8 \pm 2 \mathrm{ng} \mathrm{L}^{-1}$ after $0,1,3$, 6 , and 12 months, respectively (Fig. 2A). In the A-AC treatment however, $\mathrm{MeHg}$ concentrations in the sediment increased exponentially over the time of the experiment $\left(R^{2}=0.8299, p=0.031\right)$, ending up with a concentration $\left(199 \pm 40 \mu \mathrm{g} \mathrm{kg}^{-1}\right)$ which was 5 times higher than in the unamended control $\left(38 \pm 8 \mu \mathrm{g} \mathrm{kg}^{-1}\right)$ after 12 months. The difference between control and A-AC treatment was apparent after 3 months, at which sediment $\mathrm{MeHg}$ concentration was twice that of the control.

The A-BC treatment showed a slightly different trend than the A-AC treatment (Fig. 2A), as $\mathrm{MeHg}$ porewater concentrations decreased from the onset $\left(3.8 \pm 0.8 \mathrm{ng} \mathrm{L}^{-1}\right)$ all the way to the 6 -month mark where the concentration was 8 times lower than in the A-AC treatment (A-AC $0.8 \pm 0.1 \mathrm{ng}$ $\mathrm{L}^{-1}$ vs. A-BC $\left.0.06 \pm 0.01 \mathrm{ng} \mathrm{L}^{-1}\right)$. Similar to the A-AC treatment, an increase in porewater concentration was seen in the A-BC treatment between 6 and 12 months, from $0.06 \pm 0.01$ to $4.5 \pm 0.9 \mathrm{ng} \mathrm{L}^{-1}$. Overall, sediment $\mathrm{MeHg}$ concentrations were lower in the A-BC treatment compared to the A-AC treatment, but as for the $\mathrm{A}-\mathrm{AC}$ treatment, $\mathrm{MeHg}$ sediment contents in the A-BC treatment increased exponentially over time $\left(R^{2}=0.8122, p=0.037\right)$ and ended with a MeHg concentration 3 times higher than the control after 12 months (A-BC $116 \pm 23 \mu \mathrm{g} \mathrm{kg}^{-1}$ vs. control $38 \pm 8 \mu \mathrm{g} \mathrm{kg}^{-1}$ ). Unlike the A-AC treatment however, there was no apparent difference between $\mathrm{MeHg}$ sediment concentrations until after 12 months.

The trends of $\mathrm{THg}$ concentration in porewater were similar to those of MeHg in porewater for both the control and the two treatments over the 12-month span (Fig. 2B). In the control sample, there was a strong positive linear correlation between $\mathrm{THg}$ and $\mathrm{MeHg}$ in porewater $\left(R^{2}=0.9828\right.$, $p<0.001)$. This correlation was less strong in the amended samples $\left(R^{2}=0.6728, p=0.033\right)$.

The $\mathrm{pH}$ did not change notably over the course of the experiment however (Fig. 2D) - an initial increase was seen between the onset and 1 month, but thereafter $\mathrm{pH}$ stayed at approximately 9.5 in the control and both treatments. Alkaline ash components usually found in carbonaceous materials (Lehmann and Joseph 2015) are likely responsible for the difference in $\mathrm{pH}$ between control and treatments at $t_{0}$, but the increase to $\mathrm{pH} \approx 9.5$ is probably the cause of consumption of $\mathrm{H}^{+}$during the anaerobic reduction of labile OM (Canfield et al. 1993).

Over the course of the first month, the DOC-concentration in porewater increased 10-100 times in both the control sediment and the two sorbent-amended ones (Fig. 2E), most likely due to the labile fraction of $\mathrm{OM}$ in the added algae dissolving as has previously been observed by Ndungu et al. (2016). In the control sample, the 1-month spike in DOC-concentration 
was followed by an increase in both $\mathrm{THg}$ and $\mathrm{MeHg}$ of 15 and 44 times the concentration at $t_{0}$. Ndungu et al. (2016) recorded a similar effect in a microcosm study of an isolation capping where excess OM was added, and attributed it to ionic $\mathrm{Hg}$ partitioning from the sediment into the porewater DOC. Fluctuations in DOC-concentrations of about 10-20\% were observed between 1 and 12 months: $1200 \pm 270 \mathrm{mg} \mathrm{L}^{-1}$ in the control, $273 \pm 53 \mathrm{mg} \mathrm{L}^{-1}$ in the A-AC treatment, and $663 \pm 59 \mathrm{mg} \mathrm{L}^{-1}$ in the A-BC treatment. In the control, these fluctuations are assumed to be mainly related to anaerobic degradation of OM (Canfield et al. 1993). The approximately four- and two-times lower DOC concentrations in the A-AC and A-BC treatments, respectively, compared to the control, are attributed to sorption of OM to the ACs (Bjelopavlic et al. 1999; Schreiber et al. 2005; Schwartz et al. 2019). The higher sorption efficiency of A-AC compared to A-BC could be due to the larger share of pores $>15 \AA$ (upper micropore range and higher) in the A-AC that allows for better accommodation of large organic macromolecules (Bjelopavlic et al. 1999).

The porewater concentration of $\mathrm{SO}_{4}{ }^{2-}$ however was gradually reduced over the course of the whole experiment in both control and treatments - the concentrations were about 10 times lower after 12 months than at the start $\left(t_{0}\right)$ (Fig. 2F). This demonstrates the presence and activity of SRB in the sediment.

Overall these data show that the addition of fresh organic matter in the form of algae strongly stimulated $\mathrm{MeHg}$ formation - after 12 months, the MeHg sediment concentration in the control had increased to 45 times the initial concentration. It appears that the addition of A-AC and A-BC in combination with the algae further stimulated the formation of $\mathrm{MeHg}$, as sediment $\mathrm{MeHg}$ concentrations were 650 and 300 times higher in the A-AC and A-BC treatments, respectively, compared to the control at time zero. The apparent effect was furthermore strongest in the A-AC treatment, where the difference between control and treatment was significant after 3 months.

\subsection{Remediation efficiency}

The A-AC treatment had a strong, immediate remediation effect as $86 \%$ of $\mathrm{MeHg}$ was removed from the pore water at $t_{0}$ (Fig. 2C). The effect was at maximum after 1 month (99\%) and then declined towards $87 \%$ after 12 months. The effect of the A-BC treatment had a slower onset as only $56 \%$ was immediately sorbed at $t_{0}$. From 1 month onwards to the 6-month mark, the effect was strong (>99\%), before a drop to $93 \%$ at 12 months.

The remediation effect for $\mathrm{THg}$ was highly variable (Fig. 2C). The pool of inorganic $\mathrm{Hg}$ in the sediment was high compared to $\mathrm{MeHg}\left(0.012 \% \mathrm{MeHg}\right.$ at $\left.\mathrm{t}_{0}\right)$ and porewater THg in the control fluctuated over the 12 months of the experiment. It is likely that the ACs did not have the capacity to continuously sorb all the inorganic $\mathrm{Hg}$ released from the sediment through desorption processes. Furthermore, the apparent high THg-remediation effect seen in the first half of the experiment, i.e. $91 \%$ and $84 \%$ after 1 month and $93 \%$ and $88 \%$ after 6 months for $\mathrm{A}-\mathrm{AC}$ and $\mathrm{A}-\mathrm{BC}$ treatments, respectively (Table $\mathrm{S} 1$ ), might be partly due to biosorption of inorganic $\mathrm{Hg}$ by the Chlorella algae biomass (Kumar et al. 2020; Spain et al. 2021). However, as the algae biomass decomposes over time, biosorbed $\mathrm{Hg}$ could be released back to solution, contributing to the low remediation effect recorded at the end of the experiment (A-AC 53\% and A-BC $0 \%$; Table S1).

At $t_{0}$, the partitioning between porewater, sediment, and sorbent had not reached pseudo-equilibrium as there were no significant differences in pseudo-log $K_{D}$ between the control, A-AC, and A-BC treatments $\left(2.0,2.4\right.$, and $2.0 \log \mathrm{L} \mathrm{kg}^{-1}$, respectively $(p<0.05))$. The effect of the amendments is illustrated by an increase in $\mathrm{K}_{\mathrm{D}}$ over time as $\mathrm{MeHg}$ is produced — between 3 and 12 months, the $K_{D}$ for the amended systems were 1.5-2 log units higher than the control. At 12 months, both amendments resulted in the same $\log K_{D}\left(4.4 \mathrm{~L} \mathrm{~kg}^{-1}\right)$.

\section{Discussion}

\subsection{Methylmercury formation}

The experimental conditions, where $\mathrm{OM}$ and sulphate were in excess, strongly stimulated $\mathrm{Hg}$ methylation, as the $\mathrm{MeHg}$ concentrations of the control sample was 45 times higher after 12 months compared to $t_{0}$. The sorbent amendments seemed to stimulate methylation even further; the difference between $\mathrm{MeHg}$ sediment concentration at $t_{0}$ and 12 months were almost an order of magnitude higher in the amended samples compared to the control.

The observation that the DOC concentrations were not depleted over the course of the experiment (Fig. 2) indicates that $\mathrm{Hg}$ methylation was not limited by access to organic carbon as an electron donor in this system. Access to sulphate as an electron acceptor for SRB also did not limit $\mathrm{MeHg}$ formation in this experiment, as sulphate was not depleted after 12 months (Fig. 2). The observed gradual reduction of $\mathrm{SO}_{4}{ }^{2-}$ (Fig. 2) however shows that $\mathrm{SO}_{4}{ }^{2-}$ likely would limit methylation in this system in the long term.

The enhanced methylation seen in the amended samples is the opposite of what was hypothesized (H1). Based on observations of enhanced $\mathrm{Hg}$-methylation following biochar amendment to a salt marsh (Gilmour et al. 2018) and inundated rice paddy soils (Shu et al. 2016; Zhang et al. 2018) explained by biochar containing additional labile $\mathrm{OM}$ and/or sulphate that aided methylation, it was believed that A-AC 
and $\mathrm{A}-\mathrm{BC}$ would not enhance methylation in our system where these parameters were in excess.

The exact mechanisms of $\mathrm{Hg}$-methylation by the numerous strains of SRB that exist are still not well known, but it is generally understood that $\mathrm{MeHg}$ is a dissimilatory product of the electrochemical process of anaerobic sulphate reduction where OM typically acts as an electron donor (King et al. 1999; Merritt and Amirbahman 2009; Gilmour et al. 2011). A possible explanation of the increased $\mathrm{MeHg}$ formation in the present study is that the carbonaceous sorbents aid dissimilatory $\mathrm{Hg}$ methylation by SRB by contributing to electron shuttling between the electron donors and acceptors via their extensive aromatic free pi-electron systems (Chen et al. 2014; Yuan et al. 2017). This speculation is supported by the fact that both $\mathrm{OM}$ and $\mathrm{Hg}$ was found to sorb to the AC-sorbents used in this study, meaning that electron transfer through the AC-material between $\mathrm{OM}$ and $\mathrm{Hg}$ is a viable alternative mechanism to electron transfer during direct contact between dissolved $\mathrm{OM}$ and $\mathrm{Hg}$. Biochar has been shown to greatly affect soil redox conditions and can act as both an electron acceptor and donor due to a diverse surface functional group chemistry (Joseph et al. 2015).

Both biochar (Chen et al. 2014; Yuan et al. 2018) and AC (Liu et al. 2012) have been found to enhance methanogenesis through an electron shuttling mechanism. In biochar applied to soil, the shuttling effect was found to be augmented by quinone groups on the biochar surface that both accept and donate electrons (Yuan et al. 2018). The same mechanism has been used to explain biochar's role in contributing to increased reduction of $\mathrm{Fe}(\mathrm{III})$ minerals (Kappler et al. 2014) and Cr(VI) in soils (Xu et al. 2019). Furthermore, electron shuttling has been linked to biochar-assisted reductive debromination in sediments (Chen et al. 2018). The fact that $\mathrm{A}-\mathrm{AC}$ seemed to stimulate $\mathrm{MeHg}$ production to a larger degree than A-BC could be explained by A-AC having a higher potential for direct interspecies electron transfer as Chen et al. (2014) found when comparing biochars to previously tested ACs. To the authors' knowledge, the connection between electron shuttling and $\mathrm{AC}$ induced $\mathrm{Hg}$ methylation in sediments has not yet been demonstrated. The results from the present study are only indicative of such a mechanism, so future effort should be put into exploring this aspect.

\subsection{Sorbent amendment efficiency}

The sorption effect of both AC types for the $\mathrm{MeHg}$ was so strong that porewater concentrations were 1 to 2 orders of magnitude lower than those in the control, and even lower than those in the control at time zero before the labile OM started stimulating $\mathrm{MeHg}$ formation. It should be noted that the strong sorbent effect is observed despite the presence of high porewater DOC concentrations $\left(>200 \mathrm{mg} \mathrm{L}^{-1}\right.$; Table S1). Organic matter is known to clog pores and block potential binding sites on the sorbent surfaces (Pignatello and Xing 1996; Cornelissen et al. 2005). However, it is expected that both $\mathrm{Hg}$ and $\mathrm{MeHg}$ will be complexed with OM considering the high DOC porewater concentrations (>200 $\mathrm{mg} \mathrm{L}^{-1}$; Fig. 2E) and the low sulphide concentration (0.12 $\mathrm{mg} \mathrm{L}^{-1}$; Table 1) (Ravichandran 2004), resulting in co-sorption of $\mathrm{Hg}$ and $\mathrm{OM}$. It has previously been shown that $\mathrm{Hg}-\mathrm{OM}$ and $\mathrm{MeHg}-\mathrm{OM}$ complexes have lower partitioning coefficients to $\mathrm{AC}$ than free $\mathrm{Hg}$ (II) and $\mathrm{MeHg}$ as complexation limits $\mathrm{HgS}$ precipitation on AC surfaces (Schwartz et al. 2019). Size exclusion of large $\mathrm{Hg}-\mathrm{OM}$ and MeHg-DOC complexes from small pores should also be expected (Bjelopavlic et al. 1999). The activated biochar has a higher volume of extremely small nano/micropores (3.5-15 $\AA$ ) compared to the A-AC, that has the majority of the pore volume in the higher micropore and mesopore range (>15 ̊). Considering that both sorbents performed equally well in removing porewater $\mathrm{MeHg}$, size exclusion of $\mathrm{MeHg}$ OM complexes from narrow pores does not appear to be a limiting factor for sorbent efficiency in this case.

Strong binding of MeHg to AC and biochar has previously been reported. Gomez-Eyles et al. (2013) observed strong binding of $\mathrm{MeHg}$ to both $\mathrm{AC}$ and biochar, with an up to $92 \%$ predicted reduction in porewater concentrations upon biochar amendment. Biochar was only effective for $\mathrm{MeHg}$, not for THg. Gilmour et al. (2013) measured $\mathrm{MeHg}$ and $\mathrm{Hg}$ sorption and bioaccumulation with $\mathrm{AC}$,

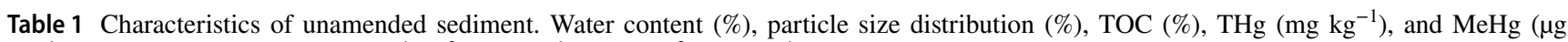
$\left.\mathrm{kg}^{-1}\right)$ of sediment. $\mathrm{pH}$, DOC $\left(\mathrm{mg} \mathrm{L}^{-1}\right), \mathrm{S}^{2-}\left(\mathrm{mg} \mathrm{L}^{-1}\right)$, and $\mathrm{SO}_{4}{ }^{2-}\left(\mathrm{mg} \mathrm{L}^{-1}\right)$ in porewater

\begin{tabular}{|c|c|c|c|c|c|c|}
\hline \multicolumn{7}{|c|}{ Untreated sediment } \\
\hline Water content $(\%)$ & Particles D $>63 \mu \mathrm{m}(\%)$ & Particles $\mathrm{D}<2 \mu \mathrm{m}(\%)$ & TOC $(\%)$ & $\mathrm{pH}$ & $\mathrm{SO}_{4}^{2-}\left(\mathrm{mg} \mathrm{L}^{-1}\right)$ & $\mathrm{S}^{2-}\left(\mathrm{mg} \mathrm{L}^{-1}\right)$ \\
\hline $84 \pm 9^{*}$ & $6.4 \pm 0.6^{*}$ & $3.0 \pm 0.3$ & $5.6 *$ & 8.1 & 900 & 0.12 \\
\hline \multicolumn{7}{|c|}{ Sediment after addition of algae biomass* } \\
\hline $\mathrm{THg}\left(\mathrm{mg} \mathrm{kg}^{-1}\right)$ & $\operatorname{MeHg}\left(\mu \mathrm{g} \mathrm{kg}^{-1}\right)$ & $\mathrm{DOC}\left(\mathrm{mg} \mathrm{L}^{-1}\right)$ & TOC $(\%)$ & $\mathrm{pH}$ & $\mathrm{SO}_{4}^{2-}\left(\mathrm{mg} \mathrm{L}^{-1}\right)$ & \\
\hline 57.1 & 0.9 & 94 & $6.6^{* *}$ & 7.6 & 1600 & \\
\hline
\end{tabular}

* Control sample at $t_{0}$

${ }^{* *}$ Calculated based on $2 \%$ addition (per d.w. sediment) of Chlorella algae with a carbon content of 50\% as reported by Ndungu et al. (2016) 
and found that $\mathrm{AC}$ bound $\mathrm{MeHg}$ strongly, especially for sediments with intrinsically weak sorption. $K_{D}$ of $\mathrm{MeHg}$ for the whole system increased at least 1 order of magnitude at AC dosages of up to $8 \%$. In contrast to the present study, formation of $\mathrm{MeHg}$ was not stimulated by the sorbent amendments - total $\mathrm{MeHg}$ sediment concentration remained constant. In another study by the same team (Gilmour et al. 2018), one of the first thin-layer capping field tests for $\mathrm{Hg}$ and $\mathrm{MeHg}$, a strong effect of $\mathrm{AC}$ was observed after 1 month (90\% reduction in porewater concentration), but this effect was not sustained for 2 years (reduced to $40 \%$ effect). Biochar, in contrast to AC, sustained a moderate effect of $40-60 \%$ reduction in porewater concentrations (Table 2).

Liu et al. (2018) carried out a 500-day microcosm experiment including pyrosequencing to study the microorganisms present. They observed clearly lower $\mathrm{MeHg}$ in porewater in the presence of $\mathrm{AC}$ and various biochar amendments. Overall $K_{D}$ of the amended systems was strongly variable (2.3 to $4.3 \log \mathrm{L} \mathrm{kg}^{-1}$ ), similar to what was observed in the present study (2.9-5.0 $\log \mathrm{L} \mathrm{kg}^{-1}$ ). There was no clear pattern of stimulation of $\mathrm{MeHg}$ formation by the amendments - MeHg sediment concentrations were not significantly different across controls and amendments and ranged from 8 to $35 \mu \mathrm{g} \mathrm{kg}^{-1}$ and are rather similar to values observed in the control of the present study $\left(0.9 \pm 0.2-38 \pm 8 \mu \mathrm{g} \mathrm{kg}^{-1}\right.$; Table S1). However, some spikes were observed, especially for the high-temperature biochars, up to $260 \mu \mathrm{g} \mathrm{kg}^{-1}$. Such spikes are in line with observations in the amended samples in the present study.

Observations of stimulation of $\mathrm{MeHg}$ formation in the sediment (Sect. 4.1) at the same time as removal of the majority of $\mathrm{MeHg}$ from the porewater by the amendments are mirrored by the trends seen in two studies on inundated anaerobic rice paddy soils. Shu et al. (2016) observed that non-activated straw biochar reduced $\mathrm{MeHg}$ uptake by rice grains (49-92\%), even though more $\mathrm{MeHg}$ was formed (20-80\% more). Thus, $\mathrm{MeHg}$ was strongly bound to biochar (MeHg in overlying water was 95\% lower) and diluted in the plants because of stimulation of crop production by $35-79 \%$. Overall, $K_{D}$ between solid and overlying water was a factor 10 higher with biochar, offsetting the $20-80 \%$ stimulation of $\mathrm{MeHg}$ formation. Similar to this study, Zhang et al. (2018)

Table 2 Pseudo $\log K_{D^{-v a l u e s}}\left(\mathrm{~L} \mathrm{~kg}^{-1}\right)$ calculated for sedimentwater distribution of $\mathrm{MeHg}$ with and without amendments at various time intervals. Error estimates based on analytical error

\begin{tabular}{llllll}
\hline Treatment & 0 months & 1 month & 3 months & 6 months & 12 months \\
\hline Control & $2.0 \pm 0.6$ & $1.7 \pm 0.5$ & $1.7 \pm 0.5$ & $2.5 \pm 0.7$ & $2.8 \pm 0.8$ \\
A-AC & $2.4 \pm 0.7$ & $2.9 \pm 0.8$ & $3.4 \pm 1.0$ & $5.0 \pm 1.3$ & $4.4 \pm 1.2$ \\
A-BC & $2.0 \pm 0.6$ & $3.3 \pm 0.9$ & $3.9 \pm 1.1$ & $5.0 \pm 1.4$ & $4.4 \pm 1.2$ \\
\hline
\end{tabular}

observed that biochar reduced $\mathrm{MeHg}$ levels in rice plants by $60 \%$ due to $64-99 \%$ lower bioavailability (as measured by thiosulfate extraction), even though soil $\mathrm{MeHg}$ levels were increased by $5-75 \%$.

All in all, the latter two rice paddy studies observed a stimulation of $\mathrm{MeHg}$ formation by sorbent amendment in the same order of magnitude as the present study. However, the overall remediation effect was less strong for $\mathrm{MeHg}$ in these studies (50-90\%) than in the present study (>95\%), probably because non-activated biochars were used, in contrast to the activated materials deployed in the present study. Activation usually leads to an increase in sorption strength of around 1 order of magnitude for hydrophobic organic compounds (Kupryianchyk et al. 2016).

Even though this study and others have shown that AC amendment can significantly reduce $\mathrm{MeHg}$ porewater concentrations, the accompanying increase of total $\mathrm{MeHg}$ contents in the sediment could be an issue of concern. Whether an AC amendment will be able to sufficiently counter such an increase over time by sorbing new $\mathrm{MeHg}$ desorbing from the sediment will depend on multiple factors: the total sorption capacity of the AC, the availability of substrates that drive methylation in the sediment, and the extent of degradation of $\mathrm{OM}$ and subsequent release of $\mathrm{MeHg}$ associated with it. Long-term studies (>12 months) or modelling such scenarios might provide the insight needed to properly understand the limitations of $\mathrm{AC}$ amendment of $\mathrm{Hg}$-contaminated sediment.

Given these considerations, the second hypothesis (H2) was confirmed: the AC sorbents efficiently reduced porewater MeHg concentrations, but further studies are needed to increase the understanding of to what extent $\mathrm{AC}$ increase Hg-methylation in sediments, and how this will affect sorbent performance in the long term.

\section{Conclusion}

Under conditions with high DOC-concentrations, that lead to complexation with $\mathrm{MeHg}$ and probably reduce the sorption of $\mathrm{MeHg}$ due to size exclusion from micropores in the sorbents, the A-AC and A-BC amendments were still able to strongly reduce the porewater concentration of $\mathrm{MeHg}$. However, these carbonaceous sorbents also seemed to contribute to an increase in the total MeHgcontents in the sediment over time. It is speculated that the effect is mainly due to the AC amendments assisting the methylation processes through electron shuttling effects, rather than the direct addition of labile OM. Future research efforts should be directed towards exploring the potential mechanisms and conditions that might allow carbonaceous sorbents to assist $\mathrm{Hg}$-methylating bacteria. 
It should be noted that in addition to the mechanistic insight this study provides, it demonstrates what could happen in a system where OM is in excess, providing good conditions for bacterial methylation of $\mathrm{Hg}$, that should be considered representative either for an organic and sulphate rich sediment, or for a scenario where large algal blooms provide such a carbon and nutrient source to a more OM poor sediment. During an event like this, there is also a risk of excess $\mathrm{OM}$ in the porewater attenuating the effect of the sorbent.

These findings demonstrate that caution is warranted when considering the use of carbonaceous sorbents for $\mathrm{Hg}$-contaminated sediment remediation. The optimal amendment scenario to avoid the formation of $\mathrm{MeHg}$ would therefore be a solution where the sorbents are not in direct contact with the Hg-contamination in the sediment, thus limiting transport out of the sediment, but not contributing to increased $\mathrm{MeHg}$ formation in the contaminated sediment. Thin capping with a layer of active sorbents (Cornelissen et al. 2012; Patmont et al. 2015) may in the case of $\mathrm{Hg}$ contamination be a better solution than complete mixing of sorbent and sediment (Ghosh et al. 2011).

Finally, this study has shown that biomass-based A-BC outperformed traditional fossil-based A-AC, as A-BC was equally effective as $\mathrm{A}-\mathrm{AC}$ in $\mathrm{MeHg}$ removal from porewater, while leading to a smaller increase in sediment $\mathrm{MeHg}$. Considering in addition that biochars offer a more sustainable sorbent remediation alternative in a life cycle perspective (Sparrevik et al. 2011; Alhashimi and Aktas 2017), activated biochars might be the best alternatives for sorbentassisted remediation of $\mathrm{Hg}$-contaminated sediments.

Supplementary Information The online version contains supplementary material available at https://doi.org/10.1007/s11368-021-03134-3.

Acknowledgements Dr. Sarah E. Hale, the project manager of NFR 243789 , is acknowledged for allocating the time of her postdoctoral researcher, and Dr. Ludovica Silvani to contribute to this study.

Author contribution Erlend Sørmo: Funding acquisition, conceptualization, methodology, investigation, formal analysis, writing — original draft, writing - review and editing. Ludovica Silvani: Investigation, writing - review and editing. Hans Fredrik Veiteberg Braaten: Methodology, writing — review and editing. Tina Bryntesen: Investigation. Espen Eek: Conceptualization, writing — review and editing. Gerard Cornelissen: Supervision, funding acquisition, conceptualization, methodology, writing — original draft, writing — review and editing.

Funding Open Access funding provided by Norwegian Geotechnical Institute. The authors received funding from the Norwegian Research Council (NFR) through the Klimaforsk project "Biochar as an adaptation strategy for climate change" (NFR 243789); the joint-industry sustainability (BIA-X) project "Valorization of Organic Waste into Sustainable Products for Clean-up of Contaminated Water, Soil, and Air" (VOW) (NFR 299070); and the NGI base funding.
Data availability All raw data produced for this study is included in the supplementary material.

\section{Declarations}

Conflict of interest The authors declare no competing interests.

Open Access This article is licensed under a Creative Commons Attribution 4.0 International License, which permits use, sharing, adaptation, distribution and reproduction in any medium or format, as long as you give appropriate credit to the original author(s) and the source, provide a link to the Creative Commons licence, and indicate if changes were made. The images or other third party material in this article are included in the article's Creative Commons licence, unless indicated otherwise in a credit line to the material. If material is not included in the article's Creative Commons licence and your intended use is not permitted by statutory regulation or exceeds the permitted use, you will need to obtain permission directly from the copyright holder. To view a copy of this licence, visit http://creativecommons.org/licenses/by/4.0/.

\section{References}

Alhashimi HA, Aktas CB (2017) Life cycle environmental and economic performance of biochar compared with activated carbon: a meta-analysis. Resour Conserv Recycl 118:13-26. https://doi. org/10.1016/j.resconrec.2016.11.016

Amirbahman A, Massey DI, Lotufo G, Steenhaut N, Brown LE, Biedenbach JM et al (2013) Assessment of mercury bioavailability to benthic macroinvertebrates using diffusive gradients in thin films (DGT). Environ Sci Process Impacts 15:2104-2114. https:// doi.org/10.1039/C3EM00355H

Amstaetter K, Eek E, Cornelissen G (2012) Sorption of PAHs and PCBs to activated carbon: coal versus biomass-based quality. Chemosphere 87:573-578. https://doi.org/10.1016/j.chemosphere. 2012.01.007

Bjelopavlic M, Newcombe G, Hayes R (1999) Adsorption of NOM onto activated carbon: effect of surface charge, ionic strength, and pore volume distribution. J Colloid Interface Sci 210:271-280. https://doi.org/10.1006/jcis.1998.5975

Bloom N, Colman J, Barber L (1997) Artifact formation of methyl mercury during aqueous distillation and alternative techniques for the extraction of methyl mercury from environmental samples. Fresenius J Anal Chem 358:371-377. https://doi.org/10. $1007 / \mathrm{s} 002160050432$

Braaten HFV, de Wit HA, Fjeld E, Rognerud S, Lydersen E, Larssen T (2014) Environmental factors influencing mercury speciation in subarctic and boreal lakes. Sci Total Environ 476-477:336-345. https://doi.org/10.1016/j.scitotenv.2014.01.030

Braaten HFV, Gundersen CB, Beylich B, Håvardstun J, Carlsson P, Bryntesen T et al (2019) Oppfølgingsunders $\emptyset$ kelse av kvikksølv i fisk fra Gunneklevfjorden og nærliggende referanseinnsjøer. NIVA-rapport; 7371. Norwegian Institute for Water Research (NIVA)

Bussan DD, Sessums RF, Cizdziel JV (2016) Activated carbon and biochar reduce mercury methylation potentials in aquatic sediments. Bull Environ Contam Toxicol 96:536-539

Canfield DE, Thamdrup B, Hansen JW (1993) The anaerobic degradation of organic matter in Danish coastal sediments: Iron reduction, manganese reduction, and sulfate reduction. Geochim 
Cosmochim Acta 57:3867-3883. https://doi.org/10.1016/00167037(93)90340-3

Carr RS, Nipper M, Adams WJ, Berry WJ, Burton Jr GA, Ho K et al (2001) Summary of a SETAC technical workshop. Porewater toxicity testing: biological, chemical, and ecological considerations with a review of methods and applications, and recommendations for future areas of research. In: Carr RS, Nipper M, Pensacola FL (eds), pp 38

Chen J, Wang C, Pan Y, Farzana SS, Tam NF-Y (2018) Biochar accelerates microbial reductive debromination of $2,2^{\prime}, 4,4^{\prime}$ tetrabromodiphenyl ether (BDE-47) in anaerobic mangrove sediments. J Hazard Mater 341:177-186. https://doi.org/10.1016/j. jhazmat.2017.07.063

Chen S, Rotaru A-E, Shrestha PM, Malvankar NS, Liu F, Fan W et al (2014) Promoting interspecies electron transfer with biochar. Sci Rep 4:5019. https://doi.org/10.1038/srep05019

Clarkson TW, Magos L, Myers GJ (2003) The toxicology of mercury-current exposures and clinical manifestations. N Engl J Med 349:1731-1737

Cornelissen G, Amstaetter K, Hauge A, Schaanning M, Beylich B, Gunnarsson JS et al (2012) Large-scale field study on thin-layer capping of marine PCDD/F-contaminated sediments in Grenlandfjords, Norway: physicochemical effects. Environ Sci Technol 46:12030-12037. https://doi.org/10.1021/es302431u

Cornelissen G, Gustafsson Ö, Bucheli TD, Jonker MTO, Koelmans AA, van Noort PCM (2005) Extensive sorption of organic compounds to black carbon, coal, and kerogen in sediments and soils: mechanisms and consequences for distribution, bioaccumulation, and biodegradation. Environ Sci Technol 39:6881-6895. https:// doi.org/10.1021/es050191b

Dai S-S, Yang Z, Tong Y, Chen L, Liu S-Y, Pan R et al (2021) Global distribution and environmental drivers of methylmercury production in sediments. J Hazard Mater 407:124700. https://doi.org/10. 1016/j.jhazmat.2020.124700

Dell'Anno A, Beolchini F, Gabellini M, Rocchetti L, Pusceddu A, Danovaro R (2009) Bioremediation of petroleum hydrocarbons in anoxic marine sediments: consequences on the speciation of heavy metals. Mar Pollut Bull 58:1808-1814

Fernandez-Luqueno F, López-Valdez F, Gamero-Melo P, Luna-Suárez S, Aguilera-González EN, Martínez AI et al (2013) Heavy metal pollution in drinking water-a global risk for human health: A review. Afr J Environ Sci Technol 7:567-584

Fick A (1855) V. On liquid diffusion. London Edinburgh Dublin Phil Mag J Sci 10:30-39. https://doi.org/10.1080/14786445508641925

Ghosh U, Luthy RG, Cornelissen G, Werner D, Menzie CA (2011) In-situ sorbent amendments: a new direction in contaminated sediment management. Environ Sci Technol 45:1163-1168. https:// doi.org/10.1021/es102694h

Gilmour C, Bell T, Soren A, Riedel G, Riedel G, Kopec D et al (2018) Activated carbon thin-layer placement as an in situ mercury remediation tool in a Penobscot River salt marsh. Sci Total Environ 621:839-848. https://doi.org/10.1016/j.scitotenv.2017.11.050

Gilmour CC, Elias DA, Kucken AM, Brown SD, Palumbo AV, Schadt CW et al (2011) Sulfate-reducing bacterium desulfovibrio desulfuricans ND132 as a model for understanding bacterial mercury methylation. Appl Environ Microbiol 77:3938-3951. https://doi. org/10.1128/aem.02993-10

Gilmour CC, Riedel GS, Riedel G, Kwon S, Landis R, Brown SS et al (2013) Activated carbon mitigates mercury and methylmercury bioavailability in contaminated sediments. Environ Sci Technol 47:13001-13010

Gomez-Eyles JL, Yupanqui C, Beckingham B, Riedel G, Gilmour C, Ghosh U (2013) Evaluation of biochars and activated carbons for in situ remediation of sediments impacted with organics, mercury, and methylmercury. Environ Sci Technol 47:13721-13729

Hagemann N, Spokas K, Schmidt H-P, Kägi R, Böhler AM, Bucheli DT (2018) Activated carbon, biochar and charcoal: linkages and synergies across pyrogenic carbon's ABCs. Water 10. https://doi. org/10.3390/w10020182

Hammerschmidt CR, Fitzgerald WF (2004) Geochemical controls on the production and distribution of methylmercury in near-shore marine sediments. Environ Sci Technol 38:1487-1495. https:// doi.org/10.1021/es034528q

Hintelmann H, Keppel-Jones K, Evans RD (2000) Constants of mercury methylation and demethylation rates in sediments and comparison of tracer and ambient mercury availability. Environ Toxicol Chem 19:2204-2211. https://doi.org/10.1002/etc.5620190909

Johnson NW, Reible DD, Katz LE (2010) Biogeochemical changes and mercury methylation beneath an in-situ sediment cap. Environ Sci Technol 44:7280-7286

Joseph S, Husson O, Graber ER, Van Zwieten L, Taherymoosavi S, Thomas $\mathrm{T}$ et al (2015) The electrochemical properties of biochars and how they affect soil redox properties and processes. Agronomy 5. https://doi.org/10.3390/agronomy5030322

Kappler A, Wuestner ML, Ruecker A, Harter J, Halama M, Behrens S (2014) Biochar as an electron shuttle between bacteria and Fe(III) minerals. Environ Sci Technol Lett 1:339-344. https://doi.org/10. 1021/ez5002209

King JK, Saunders FM, Lee RF, Jahnke RA (1999) Coupling mercury methylation rates to sulfate reduction rates in marine sediments. Environ Toxicol Chem 18:1362-1369. https://doi.org/10.1002/ etc. 5620180704

Kong H, He J, Gao Y, Wu H, Zhu X (2011) Cosorption of phenanthrene and mercury (II) from aqueous solution by soybean stalk-based biochar. J Agric Food Chem 59:12116-12123

Kumar M, Singh AK, Sikandar M (2020) Biosorption of Hg (II) from aqueous solution using algal biomass: kinetics and isotherm studies. Heliyon 6:e03321. https://doi.org/10.1016/j.heliyon.2020.e03321

Kupryianchyk D, Hale S, Zimmerman AR, Harvey O, Rutherford D, Abiven S et al (2016) Sorption of hydrophobic organic compounds to a diverse suite of carbonaceous materials with emphasis on biochar. Chemosphere 144:879-887

Lehmann J, Czimczik C, Laird D, Sohi S (2009) Stability of biochar in soil. In: Lehman J, Joseph S (ed) Biochar for environmental management: science and technology, 2nd edn. Routledge, New York, pp 183-206

Lehmann J, Joseph S (2015) Biochar for environmental management: science, technology and implementation, 2nd edn, Routledge, New York

Li Z, Wu L, Liu H, Lan H, Qu J (2013) Improvement of aqueous mercury adsorption on activated coke by thiol-functionalization. Chem Eng Sci 228:925-934. https://doi.org/10.1016/j.cej.2013. 05.063

Liu F, Rotaru A-E, Shrestha PM, Malvankar NS, Nevin KP, Lovley DR (2012) Promoting direct interspecies electron transfer with activated carbon. Energy Environ Sci 5:8982-8989. https://doi. org/10.1039/C2EE22459C

Liu P, Ptacek CJ, Blowes DW, Gould WD (2018) Control of mercury and methylmercury in contaminated sediments using biochars: a long-term microcosm study. Appl Geochemistry 92:30-44

Lutz MA, Brigham ME, Marvin-DiPasquale MC (2008) Procedures for collecting and processing streambed sediment and porewater for analysis of mercury as part of the national water-quallity assessment program. USGS Open-File Report 2008-1279. https://pubs. usgs.gov/of/2008/1279/. Accessed 12 Jan 2021

Magos L, Brown A, Sparrow S, Bailey E, Snowden R, Skipp W (1985) The comparative toxicology of ethyl-and methylmercury. Arch Toxicol 57:260-267

Marsh H, Reinoso FR (2006) Chapter 5 activation processes (thermal or physical), in Marsh H, Reinoso FR (ed) Activated carbon, 1st edn. Elsevier Science Books, pp 243-321

Merritt KA, Amirbahman A (2009) Mercury methylation dynamics in estuarine and coastal marine environments - A critical review. 
Earth Sci Rev 96:54-66. https://doi.org/10.1016/j.earscirev.2009. 06.002

Ndungu K, Schaanning M, Braaten HFV (2016) Effects of organic matter addition on methylmercury formation in capped and uncapped marine sediments. Water Res 103:401-407. https://doi.org/10. 1016/j.watres.2016.07.055

Olsen M, Fjeld E, Lydersen E (2019) The influence of a submerged meadow on uptake and trophic transfer of legacy mercury from contaminated sediment in the food web in a brackish Norwegian fjord. Sci Total Environ 654:209-217

Olsen M, Schaanning MT, Braaten HFV, Eek E, Moy FE, Lydersen E (2018) The influence of permanently submerged macrophytes on sediment mercury distribution, mobility and methylation potential in a brackish Norwegian fjord. Sci Total Environ 610-611:13641374. https://doi.org/10.1016/j.scitotenv.2017.08.136

Patmont CR, Ghosh U, LaRosa P, Menzie CA, Luthy RG, Greenberg MS et al (2015) In situ sediment treatment using activated carbon: a demonstrated sediment cleanup technology. Integr Environ Assess Manag 11:195-207. https://doi.org/10.1002/ieam.1589

Peacock M, Freeman C, Gauci V, Lebron I, Evans CD (2015) Investigations of freezing and cold storage for the analysis of peatland dissolved organic carbon (DOC) and absorbance properties. Environ Sci Process Impacts 17:1290-1301. https://doi.org/10.1039/ C5EM00126A

Pignatello JJ, Xing B (1996) Mechanisms of slow sorption of organic chemicals to natural particles. Environ Sci Technol 30:1-11. https://doi.org/10.1021/es940683g

Ravichandran M (2004) Interactions between mercury and dissolved organic matter-a review. Chemosphere 55:319-331. https://doi. org/10.1016/j.chemosphere.2003.11.011

Regnell O, Watras CJ (2019) Microbial mercury methylation in aquatic environments: a critical review of published field and laboratory studies. Environ Sci Technol 53:4-19. https://doi.org/10.1021/acs. est. 8 b02709

Schreiber B, Brinkmann T, Schmalz V, Worch E (2005) Adsorption of dissolved organic matter onto activated carbon-the influence of temperature, absorption wavelength, and molecular size. Water Res 39:3449-3456. https://doi.org/10.1016/j.watres.2005.05.050

Schwartz GE, Sanders JP, McBurney AM, Brown SS, Ghosh U, Gilmour CC (2019) Impact of dissolved organic matter on mercury and methylmercury sorption to activated carbon in soils: implications for remediation. Environ Sci Process Impacts 21:485-496. https://doi.org/10.1039/C8EM00469B

Shu R, Wang Y, Zhong H (2016) Biochar amendment reduced methylmercury accumulation in rice plants. J Hazard Mater 313:1-8. https://doi.org/10.1016/j.jhazmat.2016.03.080

Spain O, Plöhn M, Funk C (2021) The cell wall of green microalgae and its role in heavy metal removal. Physiol Plant 173:526-535. https://doi.org/10.1111/ppl.13405

Sparrevik M, Saloranta T, Cornelissen G, Eek E, Fet AM, Breedveld GD et al (2011) Use of life cycle assessments to evaluate the environmental footprint of contaminated sediment remediation. Environ Sci Technol 45:4235-4241. https://doi.org/10.1021/es103925u

Ting Y, Chen C, Ch'ng B-L, Wang Y-L, Hsi H-C (2018) Using raw and sulfur-impregnated activated carbon as active cap for leaching inhibition of mercury and methylmercury from contaminated sediment. J Hazard Mater 354:116-124. https://doi.org/10.1016/j. jhazmat.2018.04.074

Ullrich SM, Tanton TW, Abdrashitova SA (2001) Mercury in the aquatic environment: a review of factors affecting methylation. Crit Rev Environ Sci Technol 31:241-293. https://doi.org/10. 1080/20016491089226

Xu Z, Xu X, Tao X, Yao C, Tsang DCW, Cao X (2019) Interaction with low molecular weight organic acids affects the electron shuttling of biochar for Cr(VI) reduction. J Hazard Mater 378:120705. https://doi.org/10.1016/j.jhazmat.2019.05.098

Yuan H-Y, Ding L-J, Zama EF, Liu P-P, Hozzein WN, Zhu Y-G (2018) Biochar modulates methanogenesis through electron syntrophy of microorganisms with ethanol as a substrate. Environ Sci Technol 52:12198-12207. https://doi.org/10.1021/acs.est.8b04121

Yuan Y, Bolan N, Prévoteau A, Vithanage M, Biswas JK, Ok YS et al (2017) Applications of biochar in redox-mediated reactions. Bioresour Technol 246:271-281. https://doi.org/10.1016/j. biortech.2017.06.154

Zhang Y, Liu Y-R, Lei P, Wang Y-J, Zhong H (2018) Biochar and nitrate reduce risk of methylmercury in soils under straw amendment. Sci Total Environ 619-620:384-390. https://doi.org/10. 1016/j.scitotenv.2017.11.106

Publisher's Note Springer Nature remains neutral with regard to jurisdictional claims in published maps and institutional affiliations. 